\title{
Synergistic interaction between fungal cell wall degrading enzymes and different antifungal compounds enhances inhibition of spore germination
}

\author{
Matteo Lorito, $†$ Clemens Peterbauer $\ddagger$ Christopher K. Hayes \\ and Gary E. Harman
}

Departments of

Horticultural Sciences and

Plant Pathology, Cornell

University, Geneva, NY

14456, USA
Author for correspondence: Gary E. Harman. Tel: +1 315787 2246. Fax: +1 315787 2320. e-mail (internet): Gary_Harman@Cornell.Edu

Different classes of cell wall degrading enzymes produced by the biocontrol fungi Trichoderma harzianum and Gliocladium virens inhibited spore germination of Botrytis cinerea in a bioassay in vitro. The addition of any chitinolytic or glucanolytic enzyme to the reaction mixture synergistically enhanced the antifungal properties of five different fungitoxic compounds against $B$. cinerea. The chemicals tested were gliotoxin, flusilazole, miconazole, captan and benomyl. Dose response curves were determined for each combination of toxin and enzyme, and in all cases the $E D_{50}$ values of the mixtures were substantially lower than $\mathrm{ED}_{50}$ values of the two compounds used alone. For instance, the addition of endochitinase from $T$. harzianum at a concentration of $10 \mu \mathrm{g} \mathrm{ml}{ }^{1}$ reduced the $E D_{50}$ values of toxins up to 86-fold. The level of synergism appeared to be higher when enzymes were combined with toxins having primary sites of action associated with membrane structure, compared with pesticides having multiple or cytoplasmic sites of action. Among enzymes tested, the highest levels of synergism with synthetic fungicides were detected for the endochitinase from $T$. harzianum strain P1, which, when used alone, was the most effective chitinolytic enzyme against phytopathogenic fungi of those tested. The use of hydrolytic enzymes to synergistically enhance the antifungal ability of fungitoxic compounds may reduce the impact of some chemical pesticides on plants and animals.

Keywords: Botrytis cinerea, biocontrol fungi, synergistic interaction, antifungals, cell wall degrading enzymes

\section{INTRODUCTION}

The use of synthetic chemicals as fungicides is a primary method of control of disease-causing fungi in animals, including humans, and crop plants. However, the exposure of human populations and natural habitats to increasing amounts of pesticides is becoming unacceptable, and new strategies are required in the attempt to eliminate or reduce the doses of chemicals needed (Cook \& Granados, 1991). The majority of pathogenic fungi

\footnotetext{
†Permanent address: Istituto di Patologia Vegetale, Università degli Studi di Napoli, and Istituendo Centro CNR di Studio delle Tecniche di Lotta Biologica, 80055 Portici (Napoli), Italy.

$\ddagger$ Permanent address: Institut für Biochemische Technologie und Mikrobiologie, Technische Universität Wien, Wien, Austria.
}

contain chitin and 1,3- $\beta$-glucans in their cell walls (Bartnicki-Garcia, 1968), and dissolution or perturbation of these structural polymers has adverse effects upon the growth and differentiation of fungi (Poulose, 1992). Cell wall degrading enzymes (Broglie et al., 1991; Ordentlich et al., 1988), especially chitinolytic enzymes produced by biocontrol micro-organisms such as species of Trichoderma and Gliocladium (Di Pietro et al., 1993; Lorito et al., 1993a), are able to effectively control plant pathogenic fungi. These enzymes act synergistically in combination (Lorito et al., 1993a). In addition they should not be toxic to vertebrates or plants, since these organisms do not contain the target polymer. Combinations of cell wall degrading enzymes and pesticides may also act synergistically in the control of pathogenic fungi (Collins \& Pappagianis, 1974; Köller, 1992; Roberts et al., 1988; Watanabe et al., 
1988). Enzymic lysis of the cell wall may increase the uptake of chemicals into the target cell (Poulose, 1992).

The purpose of this study was to determine the occurrence of synergistic antifungal interactions between a number of fungal hydrolases and different classes of fungitoxic compounds, and to determine if the level of synergism may be related to the mechanism of action of the toxins used.

\section{METHODS}

Strains and media. Botrytis cinerea Pers. ex Fr. strain 26, provided by R. Pearson, Cornell University, was used as model test fungus. This strain was isolated from grapes, and was used previously to assay synergistic antifungal activity of chitinolytic enzymes from Trichoderma barzianum (Lorito et al., 1993a). Conidia from $B$. cinerea were produced by growing the fungus at $20-25^{\circ} \mathrm{C}$ on potato dextrose agar (PDA) (Difco) under a $16 \mathrm{~h} / 8 \mathrm{~h}$ light $/$ dark cycle. They were suspended in water, filtered through sterile Kimwipes (Kimberly-Clark) to remove hyphal fragments, and adjusted to $10^{5}-10^{6}$ propagules $\mathrm{ml}^{-1}$. T. barzianum strain P1 (ATCC 74058), which was selected for fungicide resistance from a strain originally isolated from wood chips (Tronsmo, 1991), and Gliocladium virens strain 41 (ATCC 20906), isolated from Aphanomyces suppressive soil (Smith $e t$ al., 1990), were used for the production of the chitinolytic and glucanolytic enzymes. Both strains are biocontrol agents: $T$. barzianum strain P1 is effective against $B$. cinerea (Tronsmo, 1991), whereas G. virens strain 41 is effective against Pbytophthora diseases (Smith et al., 1990) as well as other plant pathogenic fungi, including B. cinerea (G. E. Harman \& W. F. Wilcox, unpublished results).

Enzymes, enzyme assays and enzyme purification. Enzyme assays and enzyme nomenclature reported by Tronsmo \& Harman (1993) and by Harman et al. (1993) were used in this study. Four enzymes were tested. Two of these were a $41 \mathrm{kDa}$ endochitinase and a $40 \mathrm{kDa}$ chitin $1,4-\beta$-chitobiosidase (hereafter designated chitobiosidase), both from $T$. barzianum strain P1. These enzymes are strong inhibitors of a number of chitincontaining fungi, expecially when used in combination (Lorito et al., 1993a, Lorito et al., 1994), and were able to synergistically increase the effectiveness of a bacterial biocontrol agent (Lorito et al., 1993b). The third enzyme, a $78 \mathrm{kDa}$ glucan $1,3-\beta$ glucosidase (hereafter designated as glucosidase) from $T$. barzianum strain P1 (Lorito et al., 1994), also has antifungal ability in vitro against different chitinous fungi (Lorito et al., 1994). The fourth enzyme was an endochitinase from $G$. virens strain 41 that inhibited spore germination and germ tube elongation of $B$. cinerea, although at a lower level than the endochitinase from T. barzianum (Di Pietro et al., 1993).

All four enzymes were purified by the basic method described by Harman et al. (1993) and modified by Di Pietro et al. (1993) for the endochitinase from $G$. virens. Briefly the two fungal strains were grown for $5-6 \mathrm{~d}$ at $25^{\circ} \mathrm{C}$ in modified Richard's medium (Harman et al., 1993) for the production of chitobiosidase and endochitinase from T. harzianum or in SMCS medium (Di Pietro et al., 1993) for the production of glucosidase from $T$. barzianum and endochitinase from $G$. virens. The culture filtrate obtained by centrifugation and filtration was dialysed, concentrated and fractionated by gel-filtration chromatography on Sephacryl S-300 (Pharmacia LKB Biotechnology). Peak fractions containing the enzyme activity of interest were dialysed, concentrated and further purified by chromatofocusing, followed, if necessary, by isoelectric focusing in a Rotofor cell
(Bio-Rad). For the glucosidase, several peaks with glucan 1,3- $\beta$ glucosidase activity were detected after the chromatofocusing step, and fractions selected from the major activity peak were pooled, dialysed, concentrated and applied to the Rotofor cell to obtain an electrophoretically pure glucosidase, as determined by using SDS and native electrophoresis on a Phast gel electrophoresis unit (Pharmacia) (Lorito et al., 1994). Protein concentration in the enzyme preparations was determined using the Micro BCA protein assay (Pierce) with trypsin inhibitor from soybean (Sigma) as the standard protein. Enzyme solutions were kept at $4{ }^{\circ} \mathrm{C}$ and utilized for the bioassays within two weeks, or concentrated to dryness in a SpeedVac apparatus (Savant Instruments) and stored at $-20^{\circ} \mathrm{C}$ until used.

Chemical fungitoxic compounds. Different classes of fungitoxic compounds were tested: (1) gliotoxin [2,3,5a,6-tetrahydro6-hydroxy-3-(hydroxymethyl)-2-methyl-10H-3,10a-epidithiopyrazinol[1,2-a]-indole-1,4-dione] (Sigma), a naturally occurring epipolythiodiketopiperazine produced by fungi such as $G$. virens (including the strain used in this study for enzyme production) (Di Pietro et al., 1993) that selectively acts on thiol groups located on membranes (Jones \& Hancock, 1988); (2) the triazole flusilazole [bis(4-fluorophenyl)methyl-(1H-1,2,4triazol[-1-y1]-methyl)silane] (E. I. duPont de Nemours), which specifically inhibits a demethylation step in the synthesis of sterols in fungi and consequently affects membrane structure and integrity, and which is widely used in agriculture (Köller, 1992); (3) the imidazole miconazole (1-[2,4-dichloro- $\beta-([2,4-$ dichlorobenzyl]oxy)-phenethyl]imidazole) (Sigma) used in medical and veterinary therapies of fungal diseases, and which has a similar mode of action and effect to that of flusilazole (Köller, 1992); (4) benomyl (E. I. duPont de Nemours) used to control plant disease, and which inhibits mitosis by binding to $\beta$-tubulin (Ishii, 1992); (5) captan [ $N$-(trichloromethyl)thio-4cyclohexene-1,2-dicarboximide] (Stauffer), a plant protectant that binds to thiol groups and has a non-specific mode of action (Lukens, 1969).

Assay procedures. The various chemicals were dissolved or suspended in appropriate solvents. Flusilazole was dissolved in acetone, benomyl in $70 \%(\mathrm{v} / \mathrm{v})$ ethanol, miconazole in $50 \%$ $(\mathrm{v} / \mathrm{v})$ ethanol, gliotoxin in $100 \%(\mathrm{v} / \mathrm{v})$ ethanol and captan in deionized sterile water. In all cases pure compounds were employed, except for captan and benomyl, where commercially available formulations were tested. For captan two formulations were tested: a dry powder (Stauffer) and a liquid flowable formulation (Gustafson) containing $50 \%(\mathrm{w} / \mathrm{w}$ ) and $37 \%$ $(\mathrm{w} / \mathrm{v})$ active ingredient, respectively). The formulation of benomyl tested was Benlate (E. I. duPont de Nemours), a dry powder containing $50 \%(\mathrm{w} / \mathrm{w})$ active ingredient. Concentrated stock solutions or suspensions were made and progressively diluted in sterile deionized water to provide appropriate concentrations for the assay and to reduce the amount of solvent (ethanol or acetone) to non-toxic levels. Finally, diluted solutions of toxins as well as enzyme solutions (the enzymes were also dissolved in sterile deionized water) were sterilized by filtration before use in bioassays.

Assay mixtures contained $20 \mu \mathrm{l}$ of a conidial suspension $\left(10^{5}-10^{6}\right.$ conidia $\mathrm{ml}^{-1}$ ) of the test fungus $B$. cinerea, $20 \mu \mathrm{l}$ of $3 \times$ potato dextrose broth, (PDB) (Difco), $18 \mu \mathrm{l}$ of an enzyme solution (made at appropriate concentration) and $2 \mu \mathrm{l}$ of a solution or suspension of a chemical toxin (made at appropriate concentration). In the controls, sterile water was used instead of the solution containing either the enzyme or the toxin or both. In addition, the various solvent solutions were tested at the final concentrations employed to determine if they had an effect in the bioassay. Mixtures prepared as indicated above were placed in 
Table 1. $\mathrm{ED}_{50}$ values for inhibition of spore germination of $B$. cinerea for different toxins used either alone or with different amounts of fungal cell wall degrading enzymes

\begin{tabular}{|c|c|c|c|c|c|c|c|c|c|c|c|c|}
\hline \multirow{2}{*}{$\begin{array}{c}\text { Enzyme and } \\
\text { source }\end{array}$} & \multirow{2}{*}{$\begin{array}{c}\text { Concn } \\
(\mu \mathrm{g} \\
\left.\mathrm{ml}^{-1}\right)\end{array}$} & \multirow{2}{*}{$\begin{array}{c}\text { Enzyme } \\
\mathrm{ED}_{50}{ }^{*} \\
(\mu \mathrm{g} \\
\left.\mathrm{ml}^{-1}\right)\end{array}$} & \multicolumn{10}{|c|}{ Fungicide } \\
\hline & & & $\begin{array}{c}\text { Gliotoxin } \\
\text { ED }_{50}^{\dagger} \\
\left(\mathrm{ng} \mathrm{ml}^{-1}\right)\end{array}$ & $E_{\mathrm{e}}(\%) \ddagger$ & $\begin{array}{l}\text { Flusilazole } \\
\text { ED }_{\mathbf{5 0}} \dagger^{-1} \\
\left(\mathrm{ng} \mathrm{ml}^{-1}\right)\end{array}$ & $E_{\mathrm{e}}(\%) \ddagger$ & $\begin{array}{c}\text { Miconazole } \\
\text { ED }_{50}{ }^{-1} \\
\left(\mathrm{ng} \mathrm{m}^{-1}\right)\end{array}$ & $E_{\mathrm{e}}(\%) \ddagger$ & $\begin{array}{c}\text { Captan } \\
\mathbf{E D}_{50} \dagger_{1} \\
\left(\mathrm{ng} \mathrm{ml}^{-1}\right)\end{array}$ & $E_{\mathrm{e}}(\%) \ddagger$ & $\begin{array}{c}\text { Benomyl } \\
\text { ED }_{50} \dagger \\
\left(\mathrm{ng} \mathrm{ml}^{-1}\right)\end{array}$ & $E_{\mathrm{e}}(\%) \ddagger$ \\
\hline None* & & & $1250(1180-1360)$ & & $68(61-85)$ & & $3000(2890-3160)$ & & $980(850-995)$ & & $4500(4390-4900)$ & \\
\hline \multirow{4}{*}{$\begin{array}{c}\text { Endochitinase from } \\
T . \text { harzianum P1 }\end{array}$} & & 41 & & & & & & & & & & \\
\hline & & & & & & & & & & & & \\
\hline & 10 & & $190(163-220)$ & $12(10-15)$ & $0.65(0.43-1)$ & $9(9-9)$ & $70(64-89)$ & $9(9-10)$ & $310(265-364)$ & $29(27-30)$ & $1450(1220-1592)$ & $24(20-25)$ \\
\hline & 25 & & $140(132-170)$ & $29(29-29)$ & $0.31(0.22-0.45)$ & $29(29-29)$ & $46(38-51)$ & $29(28-29)$ & $60(49-80)$ & 35 (29-34) & $360(281-405)$ & $32(31-33)$ \\
\hline \multirow{4}{*}{$\begin{array}{c}\text { Chitobiosidase from } \\
\text { T. barzianum P1 }\end{array}$} & & 152 & & & & & & & & & & \\
\hline & & & & & & & & & & & & \\
\hline & 25 & & $1020(920-1100)$ & $30(26-30)$ & $1 \cdot 9(1 \cdot 6-2 \cdot 1)$ & $21(19-21)$ & $62(49-80)$ & $16(14-17)$ & $280(240-333)$ & $30(29-31)$ & $2090(1800-2335)$ & $31(27-34)$ \\
\hline & 75 & & $220(199-235)$ & $24(24-24)$ & $0.3(0.21-0.5)$ & $24(22-25)$ & $39(23-49)$ & $26(25-28)$ & $74(65-86)$ & $33(32-37)$ & $310(198-406)$ & $27(24-28)$ \\
\hline \multirow{4}{*}{$\begin{array}{l}\text { Glucosidase from } \\
\text { T. barzianum P1 }\end{array}$} & & 90 & & & & & & & & & & \\
\hline & & & & & & & & & & & & \\
\hline & 25 & & $980(885-1010)$ & $22(19-25)$ & $3.1(1.9-4.2)$ & $17(15-19)$ & $230(198-260)$ & $16(15-17)$ & $180(169-197)$ & $23(22-24)$ & $1350(1210-1430)$ & $19(19-19)$ \\
\hline & 75 & & $49(39-60)$ & $41(39-42)$ & $0.1(0.08-0 \cdot 26)$ & $39(32-38)$ & $1.5(0.8-2.5)$ & $45(44-45)$ & $19(12-29)$ & $47(46-48)$ & $140(98-186)$ & $46(43-47)$ \\
\hline \multirow{5}{*}{$\begin{array}{l}\text { Endochitinase from } \\
\text { (x, virens } 41\end{array}$} & & 195 & & & & & & & & & & \\
\hline & & & & & & & & & & & & \\
\hline & 25 & & $710(605-790)$ & $2(1-4)$ & $2 \cdot 9(1 \cdot 6-4 \cdot 1)$ & $13(10-16)$ & $82(69-98)$ & $4(6-9)$ & $93(75-129)$ & $16(15-18)$ & $1100(1005-1210)$ & $11(10-12)$ \\
\hline & 75 & & $305(285-350)$ & $24(24-25)$ & $0.38(0.29-0.6)$ & $26(26-28)$ & $48(39-60)$ & $28(28-29)$ & $40(34-50)$ & $30(29-31)$ & $280(220-339)$ & $27(25-28)$ \\
\hline & 100 & & $240(200-283)$ & $35(35-36)$ & $0.2(0.11-0.32)$ & $36(36-37)$ & $19(7-32)$ & $36(34-37)$ & $27(19-41)$ & $38(37-41)$ & $145(115-164)$ & $36(35-37)$ \\
\hline
\end{tabular}

*Values obtained by probit analysis.

${ } E D_{50}$ values for each toxin combined with the indicated amount of cell wall degrading enzyme. The initial value is the quantity of toxin required for $50 \%$ inhibition for each quantity of enzyme (with lower and upper $95 \%$ fiducial limits).

$\ddagger E_{\mathrm{e}}$ is the expected value for an additive response according to Limpel's formula, expressed as percentage inhibition (Richer, 1969). Values are provided for the expected value for additive effects of each quantity of each toxin (with similar value for the fiducial limits). The values used in Limpel's formula were those obtained from regression of percentage inhibition vs increasing toxin or enzyme concentration. In every case except with glucosidase at $75 \mu \mathrm{g} \mathrm{ml}^{-1}$, values for $E_{\mathrm{e}}$ are less than $50 \%$ inhibition, and so synergy was evident.

capped sterile Eppendorf tubes and incubated without shaking for $24-30 \mathrm{~h}$ at $25^{\circ} \mathrm{C}$. Portions of the samples were placed on microscope slides, and the germination of the first 100 conidia seen was evaluated. Spores were counted as germinated if they had germ tubes at least as long as the spore was wide. Abnormal mycelial growth and morphological anomalies such as branching, bursting, appearance of necrotic zones and lysis of the hyphal tips were also noted and photographed. Enzymes were tested at concentrations of $10,25,50,75$ and $100 \mu \mathrm{g} \mathrm{ml}^{-1}$, with values of inhibition for the enzymes used alone ranging from 0 to $73 \%$ (Lorito et al., 1993a ; Di Pietro et al., 1993). In previous experiments the dosage response curve for each single toxin was determined by testing the chemicals in the absence of enzyme. Seven different concentrations of chemical toxicants ranging from 0 to $20 \mu \mathrm{g} \mathrm{ml}^{-1}$ and providing levels of inhibition of spore germination of $B$. cinerea from 0 to $100 \%$ were chosen, and all the possible combinations with the enzymes at the five concentrations were tested in the bioassay.

Analysis of data. The results are the means of at least two experiments with three replicates for each experiment. The standard deviations were calculated from at least two experiments with 300 observations per experiment. The values of spore germination obtained for the control ranged from 70 to $95 \%$. For each experiment the means of the control values were calculated, then taken as $0 \%$ inhibition; all other values were divided by these values and multiplied by 100 to obtain percentage inhibition. According to Richer (1987), the following (Limpel's) formula was used to determine the presence of antifungal synergistic interactions between chitinases and fungicides: $E_{\mathrm{e}}=(X+Y-X Y) / 100$, where $E_{\mathrm{e}}$ is the expected effect from additive responses of two inhibitory compounds, and $X$ and $Y$ are the percentages of inhibition relative to each compound used alone. If the combination of the two agents produces any value of inhibition greater than $E_{\mathrm{e}}$, synergism exists, and the difference is proportional to the level of synergism observed. For each toxin, for each enzyme or for each toxin/enzyme combination, dosage response curves were obtained by probit analysis of the data. The lower and the upper $95 \%$ fiducial limits for $95 \%$ probability were obtained by probit analysis. $\mathrm{ED}_{50}$ values for each enzyme, each toxin and each combination of enzyme and toxin were also calculated by probit analysis.

\section{RESULTS}

Every pesticide/enzyme combination tested inhibited spore germination of $B$. cinerea and showed a substantial level of synergism (Table 1, Figs 1 and 2). In Table 1 we present the quantities of toxin required to obtain $50 \%$ inhibition of $B$. cinerea spore germination, together with the $95 \%$ fiducial limits for these values. For enzyme/ fungicide mixtures we also present the inhibition levels $\left(E_{\mathrm{e}}\right)$ expected for these quantities of enzymes and chemicals if only additive effects occurred. In most cases, $E_{\mathrm{e}}$ was substantially lower than the value of inhibition actually observed for the mixtures, indicating that synergy did occur (Table 1). Further, $E_{\mathrm{e}}$ values were outside the values calculated for the fiducial limits, indicating that synergy was significant.

The nature of the chemical fungitoxicant affected the level 

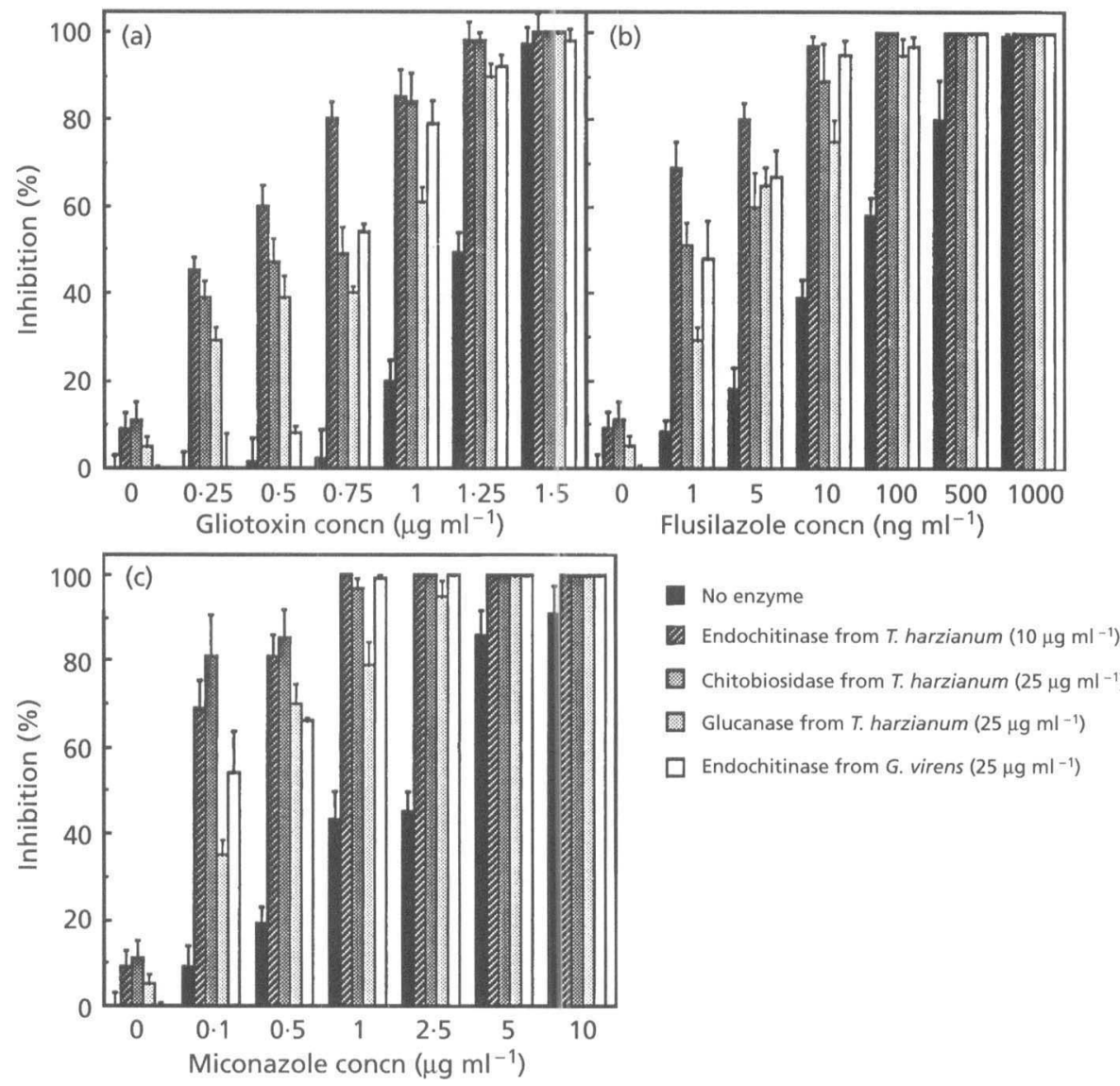

Fig. 1. Inhibition of $B$. cinerea spore germination by gliotoxin (a), flusilazole (b) and miconazole (c) in the presence of different cell wall degrading enzymes from $T$. harzianum strain $\mathbf{P 1}$ and $G$. virens strain 41 , or in the absence of enzymes. The hydrolytic enzymes were tested in combination with the toxins at five concentrations, 10, 25, 50,75 and $100 \mu \mathrm{g} \mathrm{ml} \mathrm{l}^{-1}$, although only one concentration for each protein is represented in the figure. The values of inhibition are means from two experiments with three replicates for each experiment. Error bars indicate standard deviations, calculated from at least two experiments with 300 observations per experiment.

of synergism. For most of the combinations of pesticide/ enzyme, the level of synergism was higher when a cell wall degrading enzyme was associated with gliotoxin, flusilazole or miconazole as opposed to captan or benomyl (Table 1). The $\mathrm{ED}_{50}$ values of the combinations between enzymes and gliotoxin, flusilazole or miconazole were lower compared with mixtures containing enzymes and captan or benomyl (Table 1, Fig. 1). For instance, the addition of endochitinase $\left(10 \mu \mathrm{g} \mathrm{ml}^{-1}\right)$ from $T$. harzianum strain $\mathrm{P} 1$ reduced the $\mathrm{ED}_{50}$ values 6.5-, 104- and $42 \cdot 8$-fold for gliotoxin, flusilazole and miconazole, respectively, whereas the reduction for either captan or benomyl was 3.1-fold (Table 1, Figs 1 and 2). When cell wall degrading enzymes were combined with the same pesticide, the level of synergism expressed was higher for endochitinase from $T$. harzianum. This enzyme, when used alone, was more effective than any other enzyme (Lorito et al., 1993a) (Table 1). Similarly, the addition of $1 \mathrm{ng}$ flusilazole $\mathrm{ml}^{-1}$ reduced the $\mathrm{ED}_{50}$ value $6 \cdot 8$-fold for endochitinase from $T$. harzianum, and 4.6-, 1.3- and 3.9-fold for chitobiosidase and glucosidase from $T$. barzianum and endochitinase from G. virens, respectively.
There were no differences between the two formulations of captan used in this study, and the data shown were obtained with the dry formulation.

\section{DISCUSSION}

This paper used spore germination as the criterion of fungitoxicity of pesticides and enzymes. However, both chemical fungicides and enzymes have effects upon other stages of the fungal life cycle. In our earlier work (Lorito et al., 1993a), we showed that effects on hyphal elongation were very closely correlated with inhibition of spore germination. In addition, both enzymes and chemicals induce a number of morphological abnormalities within hyphae, including, in the case of enzymes, bursting of vegetative cells (Lorito et al., 1993a).

The ability of cell wall degrading enzymes to interact synergistically in degradation of substrates has been reported by several authors (De La Cruz et al., 1992; Lorito et al., 1993a; Mauch et al., 1988; Nevalainen $e t$ al., 1991). In addition, plant chitinases were synergistic with 

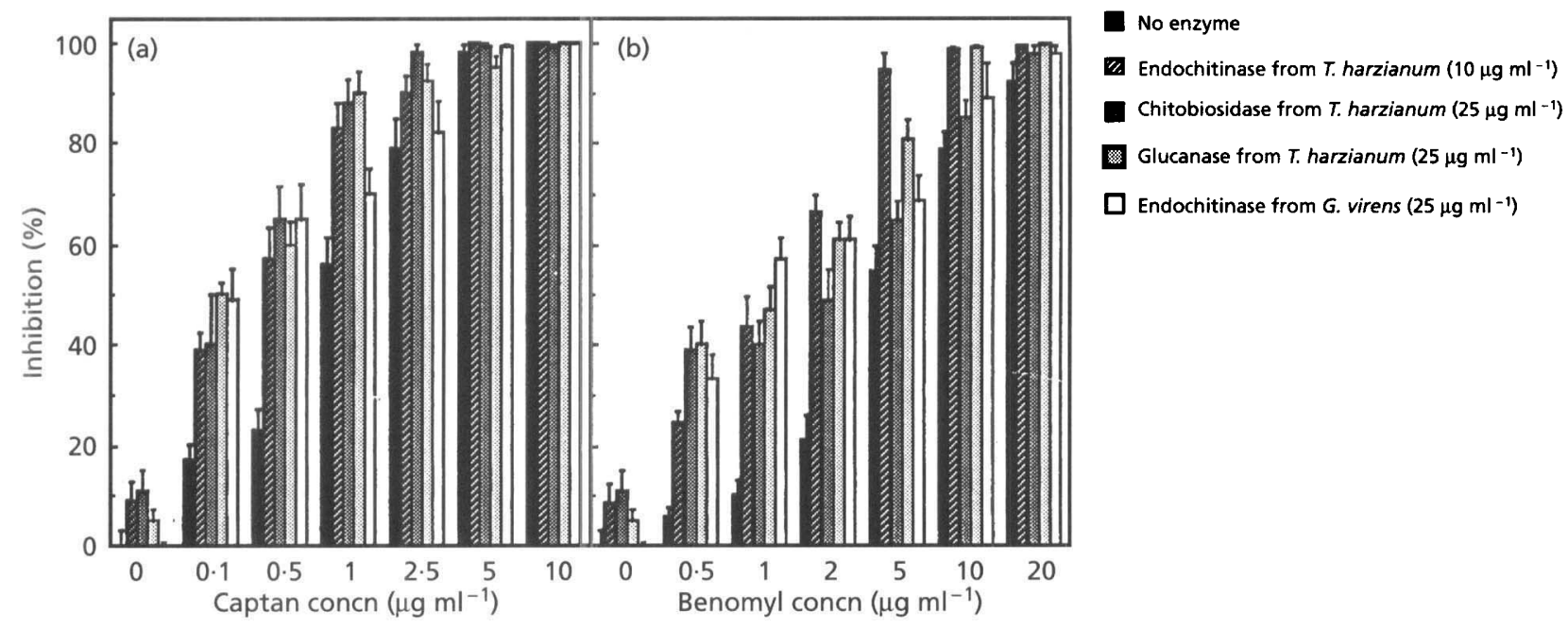

Fig. 2. Inhibition of $B$. cinerea spore germination by captan (a) and benomyl (b) in the presence of four different cell wall degrading enzymes from $T$. harzianum strain P1 and $G$. virens strain 41 , or in the absence of enzymes. The hydrolytic enzymes were tested in combination with the toxins at five concentrations, $10,25,50,75$ and $100 \mu \mathrm{g} \mathrm{ml}^{-1}$, although only one concentration for each protein is represented in the figure. The values of inhibition are means from two experiments with three replicates for each experiment. Error bars indicate standard deviations, calculated from at least two experiments with 300 observations per experiment.

inhibitors of chitin synthesis in fungi, such as polyoxin B and nikkomycin (Roberts et al., 1988; Poulose, 1992). The results obtained in this study showed that different cell wall degrading enzymes substantially enhanced the activity of a variety of chemical and natural fungitoxic compounds. The chemicals chosen had different modes of action (Köller, 1992; Jones \& Hancock, 1988; Miller, 1969; Ishii, 1992); thus the ability of the enzymes to synergistically interact with the pesticides tested was not associated with a single class of compounds. The mechanism(s) for the synergism observed in this study is unknown. One possibility is that digestion of the cell wall may enhance the uptake of the chemicals. However, differences in the level of synergism were detected between toxins having direct effects on membranes versus other antifungal compounds with non-specific modes of action or with specific sites of action on cytoplasmic components. We found that the highest levels of synergism occurred with two sterol demethylation inhibitors and with gliotoxin. Gliotoxin has a direct effect upon membranes (Jones \& Hancock, 1988), while demethylation inhibitors inhibit sterol synthesis (Köller, 1992). Sterols are required for structure and function of membranes (Vanden Bossche, 1989), and so both classes of highly synergistic toxicants have significant and primary effects upon membranes. These findings suggest that combining the effect of these toxins with partial digestion of cell walls may be particularly damaging for the targeted cells and, therefore, may reduce the lethal doses of the toxins. In addition, fungi, including Botrytis allii, treated with sterol demethylation inhibitors showed an irregular deposition of chitin in the fungal cell wall possibly as result of a functional imbalance in the chitin synthase system (Köller, 1992). Therefore, the ability of cell wall degrading enzymes to increase the intracellular dose of the toxins may also lead to a further disorganization of the cell wall and consequently to more effective lytic action of the enzyme. This synergistic feedback loop may be started at relatively low doses of the two agents and may also be responsible for the high level of synergistic antifungal interaction observed with sterol demethylation inhibitors.

The relative sensitivity of Pythium ultimum and Rbizoctonia solani to gliotoxin was affected by the presence or the integrity of diffusion barriers such as the fungal cell wall (Jones \& Hancock, 1988). Di Pietro et al. (1993) discovered the ability of this natural fungicide to interact synergistically with an endochitinase produced from a strain of $G$. virens during the inhibition of $B$. cinerea which may be involved in the biocontrol ability of these fungi. Our findings confirmed these results and also showed that several cell wall lytic enzymes from different biocontrol fungi, including strain P1 of T. harzianum, which does not produce gliotoxin, were able to increase the antifungal effect of five different toxins. This suggests that synergism between toxins and enzymes may be a quite common event, since the co-production of cell wall lytic enzymes and toxic metabolites probably occurs commonly among biocontrol agents.

A number of authors have suggested the possibility of using cell wall degrading enzymes as adjuvants of fungicidal or fungitoxic compounds (Poulose, 1992). The results of this study expand the range of useful combinations of fungicides and enzymes and indicate that the level of synergism may be affected by the mode of action of the compounds. These findings may also be useful in designing effective combinations to be tested, in which synergism is likely to occur at high levels. In some cases, either the enzyme or the producing organism may be used in association with antimycotic drugs. For instance, 
combining captan with T. harzianum, which is resistant to this fungicide, resulted in greater control of Verticillium dabliae on potato than either agent used singly (Ordentlich et al., 1990). The reasons for this interaction in vivo between captan and Trichoderma have not been investigated, although our results suggest that cell wall degrading enzymes could play a role in this synergism. While this study examined effects of enzymes and antifungal compounds only on $B$. cinerea, chitinolytic enzymes from $T$. barzianum have been shown to act synergistically against a wide range of disease-causing fungi in the Ascomycetes, Deuteromycetes and Basidiomycetes (Lorito et al., 1993a). Therefore, the synergistic activities of enzymes and chemical fungicides reported here are also likely to apply to a wide range of chitinous fungi.

These results, therefore, suggest that combinations of fungal cell wall degrading enzymes and synthetic pesticides may be useful in a range of agricultural applications, and perhaps even in veterinary or human medicine. Davies \& Pope (1978) demonstrated that a mixture of chitinolytic enzymes and chemical antifungal agents had useful antimycotic activity in immunosuppressed laboratory animals. Enzymes and chemicals might be topically applied or introduced in other ways. For example, the possibility of producing transgenic plants resistant to plant pathogenic fungi via production of fungal cell wall degrading enzymes has been attempted, but only a moderate level of resistance has been achieved (Broglie $e t$ al., 1991). This difficulty may be overcome by introducing several genes coding for synergistic antifungal enzymes; our data indicate that $\mathrm{ED}_{50}$ levels may be reduced 100 fold by such combinations (Lorito et al., 1993a). Alternatively, or in addition, pesticides synergistic with the expressed enzymes may be applied. The data in this work indicate that the presence of even low levels of enzymes may increase the sensitivity of pathogenic fungi by 1-2 orders of magnitude. Thus, very low levels of demethylation inhibitors may be sufficient to eliminate plant disease that does occur on transgenic plants. Assuming that levels of synergy in vivo equivalent to the synergy in vitro reported here can be obtained, a number of strategies can be envisioned for use of synergistic chemical and enzymic agents with a substantial reduction in the rate of chemical protectant applied.

\section{ACKNOWLEDGEMENTS}

The authors thank W. Köller, Cornell University, Geneva, NY, for helpful information, suggestions and discussion, R. M. Broadway, Cornell University, for the critical revision of the manuscript, R. Pearson, Cornell University, for providing the strains of Botrytis cinerea used in this study and G. Nash and P. Nielsen, Cornell University, for their technical assistance. This research was supported in part by BARD Grant US-172389 . The first author was supported by a grant from the National Council of Research (CNR), Italy.

\section{REFERENCES}

Bartnicki-Garcia, S. (1968). Cell wall chemistry, morphogenesis, and taxonomy of fungi. Annu Rev Microbiol 22, 87-108.
Broglie, K., Chet, I., Holliday, M., Cressman, R., Biddle, P., Knowlton, S., Mauvais, C. J. \& Broglie, R. (1991). Transgenic plants with enhanced resistance to the fungal pathogen Rbizoctonia solani. Science 254, 1194-1197.

Collins, M. S. \& Pappagianis, D. (1974). Lysozyme enhanced killing of Candida albicans and Coccidioides immitis by amphotericin B. Sabouraudia 12, 329-340.

Cook, R. J. \& Granados, R. R. (1991). Biological control: making it work. In Agricultural Biotecbnology at the Crossroads, pp. 213-227. Edited by M. J. F. MacDonald. Ithaca, NY : National Agricultural Biotechnology Council.

Davies, D. A. L. \& Pope, A. M. S. (1978). Mycolase, a new kind of systemic antimycotic. Nature 273, 235-236.

De La Cruz, J., Hidalgo-Gallego, A., Lora, J. M., Benitez, T., PintorToro, J. A. \& Llobell, A. (1992). Isolation and characterization of three chitinases from Trichoderma barzianum. Eur $J$ Biochem 206, 859-867.

Di Pietro, A., Lorito, M., Hayes, C. K., Broadway, R. M. \& Harman, G. E. (1993). Endochitinase from Gliocladium virens: isolation, characterization and synergistic antifungal activity in combination with gliotoxin. Phytopathology 83, 308-313.

Harman, G. E., Hayes, C. K., Lorito, M., Di Pietro, A., Broadway, R. M. \& Tronsmo, A. (1993). Chitinolytic enzymes produced by Trichoderma barzianum: purification of chitobiosidase and endochitinase. Phytopatbology 83, 313-318.

Ishii, H. (1992). Target sites of tubulin-binding fungicides. In Target Sites of Fungicide Action, pp. 43-52. Edited by W. Köller. Boca Raton, FL: CRC.

Jones, R. W. \& Hancock, J. G. (1988). Mechanism of gliotoxin action and factors mediating gliotoxin sensitivity. $J$ Gen Microbiol 134, 2067-2075.

Köller, W. (1992). Antifungal agents with target sites in sterol functions and biosynthesis. In Target Sites of Fungicide Action, pp. 119-206. Edited by W. Köller. Boca Raton, FL: CRC.

Lorito, M., Harman, G. E., Hayes, C. K., Broadway, R., Tronsmo, A., Woo, S. L. \& Di Pietro, A. (1993a). Chitinolytic enzymes produced by Trichoderma barzianum: antifungal activity of purified endochitinase and chitobiosidase. Phytopatbology 83, 302-307.

Lorito, M., Di Pietro, A., Hayes, C. K., Woo, S. L. \& Harman, G. E. (1993b). Antifungal, synergistic interaction between chitinolytic enzymes from Trichoderma barzianum and Enterobacter cloacae. Phytopathology 83, 721-728.

Lorito, M., Hayes, C. K., Di Pietro, A., Woo, S. L. \& Harman, G. E. (1994). Purification of chitinolytic and glucanolytic enzymes from Trichoderma barzianum and their synergistic activity against Botrytis cinerea. Phytopatbology 84 (in press).

Lukens, R. J. (1969). Heterocyclic nitrogen compounds. In Fungicides, vol. II, pp. 395-445. Edited by D. C. Torgeson. New York: Academic Press.

Mauch, F., Mauch-Mani, B. \& Boller, T. (1988). Antifungal hydrolases in pea tissue. II. Inhibition of fungal growth by combinations of chitinase and $\beta-1,3$-glucanase. Plant Pbysiol 88, 936-942.

Miller, L. P. (1969). Mechanism for reaching the site of action. In Fungicides, pp. 2-51. Edited by D. C. Torgeson. New York: Academic Press.

Nevalainen, H. K. M., Penttilla, M. E., Harkki, A., Teeri, T. T. \& Knowles, J. (1991). The molecular biology of Trichoderma and its application to expression of both homologous and heterologous genes. In Molecular Industrial Mycology, pp. 129-148. Edited by S. A. Leong \& R. M. Berka. New York: Marcel Dekker.

Ordentlich, A., Elad, Y. \& Chet, I. (1988). The role of chitinase of 
Serratia marcescens in biocontrol of Sclerotium rolfsii. Pbytopathology 78, 84-88.

Ordentlich, A., Nachmias, A. \& Chet, I. (1990). Integrated control of 1 erticillium dabliae in potato by Trichoderma harzianum and captan. Crop Prot 9, 363-366.

Poulose, A. J. (1992). Biotechnology and fungal control. In Target Sites of Fungicide Action, pp. 311-318. Edited by W. Köller. Boca Raton, FL: CRC.

Richer, D. L. (1987). Synergism - a patent view. Pestic Sci 19, 309-315.

Roberts, W. K., Laue, B. E. \& Selitrennikoff, C. P. (1988). Antifungal proteins from plants. Ann NY Acad Sci 544, 141-151.

Smith, V. L., Wilcox, W. F. \& Harman, G. E. (1990). Potential for biological control of Phytophthora root and crown rots of apple by Trichoderma and Gliocladium spp. Pbytopathology 80, 880-885.
Tronsmo, A. (1991). Biological and integrated controls of Botrytis cinerea on apple with Trichoderma barzianum. Biol Control 1, 59-62.

Tronsmo, A. \& Harman, G. E. (1993). Detection and quantification of $N$-acetyl- $\beta$-D-glucosaminidase, chitobiosidase, and endochitinase in solution and on gels. Anal Biochem 208, 74-79.

Vanden Bossche, H. (1989). Importance and role of sterols in fungal membranes. In Biocbemistry of Cell Walls and Membranes in Fungi, pp. 135-157. Edited by P. J. Kuhn, A. P. J. Trinci, M. J. Jung, M. W. Goosey \& L. G. Copping. Berlin: Springer-Verlag. Watanabe, R., Ogasawara, N., Tanaka, H. \& Uchiyama, T. (1988). Effects of fungal lytic enzymes and non-ionic detergents on the actions of some fungicides against Pyricularia oryzae. Agric Biol Chem 52, 895-901.

Received 18 August 1993; accepted 28 September 1993. 